Pediatr. Res. 17: 82 (1983)

\title{
Letter to the Editor: Neonatal Hypocalcemia in Preterm Infants
}

\author{
B. SALLE
}

Neonatal Department, Hôpital Edouard-Herriot, Lyon, France

Romagnoli et al. demonstrated clearly as we have published (1) that administration of $25(\mathrm{OH}) \mathrm{D}$ did not modify the course of serum calcium during the first week of life and did not prevent the early type of hypocalcemia. We are in perfect agreement that early calcium administration either intravenously (2) or orally (3) increases calcemia and prevents the decrease of serum calcium.

$25(\mathrm{OH}) \mathrm{D}$ per se does not play any role in intestinal $\mathrm{Ca}$ absorption and only its metabolite $1,25\left(\mathrm{OH}_{2}\right) \mathrm{D}$ has an effect on this phenomena. We have published that in premature more than 32 wk of gestation, $25(\mathrm{OH}) \mathrm{D}$ is well hydroxylated in the kidney and the serum level of 1,25 $\left(\mathrm{OH}_{2}\right) \mathrm{D}$ depends on the serum level of $25(\mathrm{OH}) \mathrm{D}(4)$. We agree that a defect of vitamin $\mathrm{D}$ metabolism is not the primary pathogenic factor of this type of hypocalcemia.

Administration over a long period of $25(\mathrm{OH}) \mathrm{D}$ seems to us not to be warranted because of the half-life of this compound (21-25 days) and furthermore administration of vitamin $D$ at a sufficient dosage is safer and cheaper.

As for the late neonatal hypocalcemia, it is a different problem. Hypoparathyroidism is the primary factor (5) and administration of $1,25\left(\mathrm{OH}_{2}\right) \mathrm{D}$ is the most reliable treatment. In our experience administration of $25(\mathrm{OH}) \mathrm{D}$ or vitamin $\mathrm{D}$ does not prevent this disorder.

\section{REFERENCES AND NOTES}

1. Salle, B., David, L., Glorieux, F. H., Delvin, E., Senterre, J., and Renaud, H. Early oral administration of vitamin $\mathrm{D}$ and its metabolites in premature neonates. Effect on mineral homeostasis. Pediatr. Res., 16: 75 (1982).

2. Salle, B., David, L., Chopard, J. P., Grafmeyer, D. C., and Renaud, H.: Prevention of early neonatal hypocalcemia in low birth weight infants with continuous calcium infusion: effect on serum calcium, phosphorus, magnesium, and circulating immunoreactive parathyroid hormone and calcitonin. Pediatr. Res. 11: 1180 (1977).

3. Brown, D. R., Tsang, R. C., and Chen, I. W.: Oral calcium supplementation in premature and asphyxiated neonates. J. Pediatr., 89: 973 (1976).

4. Glorieux, F. H., Salle, B. L., Delvin, E. E., and David, L.: Vitamin D metabolism in preterm infants: serum calcitriol values during the first five days of life. $J$. Pediatr., 99: 640 (1981).

5. Salle, B., David, L., Varenne, P., Glorieux, F., Delvin, E.: Treatment of late neonatal hypocalcemia with 1 alpha hydroxycholecalciferol (10HCC). European Society for Pediat Res., Berne, Switzerland, September 24-26,1981. Abstract in Pediatr. Res., 15: 1222 (1981). 